\title{
Inheritance of resistance to powdery mildew in pea and pathogenesis-related aspects
}

\author{
Ricardo Lima dos Santos ${ }^{1 *}$; Marcelo Agenor Pavan², Norberto da Silva²; Leandro Augusto Andrade Fumes ${ }^{3}$
}

${ }^{1}$ Doutorando em Agronomia, UNESP, Faculdade de Ciências Agronômicas, CEP18603-970 Botucatu, SP. Pesquisador Fitomelhorista, **Sakata Seed Sudamerica Ltda. Av. Dr. Plínio Salgado, 4320, CEP12906840 Bragança Paulista, São Paulo.

${ }^{2}$ Professor Titular, Departamento de Produção Vegetal, UNESP, Faculdade de Ciências Agronômicas, CEP 18603-970, Botucatu,SP. ${ }^{3}$ Mestrando em Genética e Melhoramento de Plantas ESALQ/USP. *Parte da dissertação do primeiro autor. **Endereço para correspondência Autor para correspondência: Ricardo Lima dos Santos (ricardo.lima@sakata.com.br)

Data de chegada: 13/06/2011. Aceito para publicação em: 13/02/2012.

1760

\section{ABSTRACT}

Santos, R.L.; Pavan, M.A.; Silva, N.; Fumes, L.A.A. Inheritance of resistance to powdery mildew in pea and pathogenesis-related aspects Summa Phytopathologica, v.38, n.2, p.119-122, 2012.

The inheritance of resistance to powdery mildew in the pea cultivar MK-10 and some histological aspects of infection were assessed. For the inheritance study, F1, F2, backcrosses and F3 generations of MK-10 crossed with two susceptible populations were evaluated. Histological evaluations included percentage of germinated conidia, percentage of conidia that formed appresoria, percentage of conidia that established colonies, and number of haustoria per colony.
Segregation ratios obtained in the resistance inheritance study were compared by Chi-square $\left(x^{2}\right)$ test and the histological data were analyzed by Tukey's test at $5 \%$ probability. It was concluded that resistance of MK-10 to powdery mildew is due to a pair of recessive alleles since it is expressed in the pre-penetration stage and completed by post-penetration localized cellular death, characteristic of the presence of the pair of recessive alleles erlerl.

Additional keywords: Erysiphe pisi, genetic resistance, host-pathogen interaction, MK-10, histology.

\section{RESUMO}

Santos, R.L.; Pavan, M.A.; Silva, N.; Fumes, L.A.A. Herança da resistência a oídio em ervilha e aspectos relacionados á patogênese. Summa Phytopathologica, v.38, n.2, p.119-122, 2012.

A herança da resistência ao oídio na cultivar de ervilha MK10 e alguns aspectos histológicos da infecção foram estudados. Para o estudo da herança, as gerações F1, F2, retrocuzamentos e geração F3 de MK-10 com duas populações suscetíveis foram avaliadas. Nas avaliações histológicas observou-se a porcentagem de conídios germinados, porcentagem de conídios que formaram apressório, porcentagem de conídios que estabeleceram colônia e número de haustórios por colônia. Para comparar as razões de segregação obtidas no estudo da herança da resistência, adotou-se o teste do Qui-quadrado $\left(X^{2}\right)$ e para os dados das análises histológicas, utilizou-se o teste Tukey a 5\% de probabilidade. Concluiu-se que a resistência de MK-10 ao oídio é devida a um par de alelos recessivos e que a resistência é expressa na fase de prépenetração, completada por uma morte celular localizada póspenetração, característica da presença do par de alelos recessivos erlerl.

Palavras-chave adicionais: Erysiphe pisi, resistência genética, interação patógeno-hospedeiro, MK-10, histologia.

Pea (Pisum sativum L.) is an important vegetable grown in Brazil and used for consumption as fresh immature seeds or immature pod and seeds.

Powdery mildew, caused by the Ascomycota Erysiphe pisi DC, is the most important disease affecting pea and causing significant yield losses (13). Fungicide spraying is the most common method to control this disease (9) but the use of cultivars resistant to powdery mildew is an interesting alternative. In fact, several pea cultivars resistant to powdery mildew were released in Brazil $(6,7)$, and the cultivar Triofin has been used as source of resistance. In the latter cultivar, resistance is characterized by sparse mycelial growth, and genetic control is polygenic (5).
Three other sources of resistance to powdery mildew are currently known: Mexique 4, Stratagem and Svp952; they carry one or two recessive genes named $e r_{1}$ and $e r_{2}(8,12)$ which are easier to be utilized in breeding programs.

Recently, a new edible pod pea, called MK-10, was released in Brazil by a seed company (Sakata Sudamerica, 2005), showing high resistance level to powdery mildew which is phenotypically expressed as absence of fungal mycelia on the leaves and stems of resistant plants.

The use of that source to develop new pea cultivars requires the elucidation of the genetic basis of resistance to powdery mildew in MK-10 and the establishment of some histological aspects of $E$. pisi infection in it. This is the aim of the present study. 


\section{MATERIALAND METHODS}

Inheritance study: Cultivar MK-10, the source of resistance to E. pisi, was crossed with an edible pod pea breeding line L-802 and with cultivar No. 40 , both susceptible to powdery mildew. Crosses were made in the flower bud stage after emasculation of anthers and before pollen shed. Several genetic dominant markers, such as plant color, presence of anthocyanin, cotyledon color and texture, and brown marbling of seed testa, from which parents differ, were used to discard any possible contamination in different crosses. Self-fertilization of $F_{1}$ originated $F_{2}$ populations; $F_{1}$ plants crossed with parental lines, originating backcross generations for resistant and susceptible parents in each case.

Evaluation of different generations for powdery mildew resistance was performed in the experimental farm of the School of Agronomical Sciences, UNESP-Univ Estadual Paulista "Júlio de Mesquita Filho", Brazil, under plastic house conditions during autumn and winter months. Temperatures ranged from $15^{\circ}$ to $28^{\circ} \mathrm{C}$ during the experimental period. Parental lines MK-10, L-802 and No. 40, as well as a susceptible line 'Snap' were planted with F1, F2 and backcross generations in a completely randomized design. Plants were grown $0.30 \mathrm{~m}$ apart in rows spaced $0.8 \mathrm{~m}$ and were tied to stakes used to support vine growth to allow evaluations during plant cycle.

No inoculation of the fungus was made, but to ensure a natural and generalized disease occurrence, one plant of the susceptible edible pod pea 'Torta de Flor Roxa' was planted after each ten plants of parental and segregant generations. Identification and recording of resistant and susceptible plants started when interplanted control were uniformly infected and continued until plants were almost dry at the end of their life cycle. The criteria for resistance or susceptibility were absence or presence of traces of the pathogen mycelia on the plants, compared with the resistant parental control MK-10.

Self-fertilized seeds from resistant and susceptible $\mathrm{F}_{2}$ plants were individually harvested and $\mathrm{F}_{3}$ progenies were grown in the next season together with the susceptible lines (L-802 and No. 40) and the resistant line MK-10; the same procedures were followed to assess F1, F2 and backcross generations, including interplanting of the susceptible cultivar 'Torta de Flor Roxa' as control for the disease spread.

The purpose of the progeny test was to rule out possible escapes or F2 plant misclassification, as well as to confirm the proposed mode $\mathrm{f}$ inheritance to powdery mildew resistance based on F1, F2 and backcross generations.

Phenotypic proportions observed in segregant generations were compared to the expected ones by adopting Chi-square test $\left(\mathrm{X}^{2}\right)$ as described by Strickberger (14).

Histological analysis. During evaluation of parental and $F_{2}$ generations from the crosses L-802 x MK-10 and No. 40 x MK-10, and when the pathogen was evenly distributed on the plants, the method proposed by Fondevilla et al. (4) was used to establish histological aspects of the infection related to the presence of different genes providing resistance to powdery mildew. The susceptible cultivar 'Torta de Flor Roxa' was also included in the analysis.

Five leaflets from five resistant and five susceptible plants, from each population, were randomly collected. Foliar disks with $20 \mathrm{~mm}$ diameter were placed on Petri dishes and transferred to a BOD incubator at $20 \pm 1{ }^{\circ} \mathrm{C}$ and 12 -hour photoperiod for 48 hours. Then, foliar disks were placed with their abaxial face upwards on
Petri dishes containing moistened filter paper and water-free acetic acid plus ethanol (1:3) for 2 hours. As soon as the leaflets showed a faded color, they were transferred to filter paper moistened with water for additional 2 hours and then moved to filter paper moistened with lactoglycerol (1:1:1 lactic acid:glycerol:water) for 2 hours. For visualization under 200x magnification microscope, foliar disks were stained with $0.2 \%$ methyl blue solution in $95 \%$ ethanol (2).

The percentage of germinated spores with appresorium that established a colony (percentage of colonization) was evaluated. Then, leaf disks were immersed in $0.05 \%$ trypan blue solution in lactophenol and ethanol (1:2) for one hour at $60^{\circ} \mathrm{C}$ and observed under 400x differential interference contrast microscope, where the number of haustoria per colony was counted.

Data for both parameters underwent analysis of variance and means were compared by Tukey's test at $5 \%$ probability level.

\section{RESULTS AND DISCUSSION}

Inheritance study. Powdery mildew epidemic in pea plants grown in a plastic house started at 60 days after planting, when a high infection rate was noticed for interplanted plants of the susceptible cultivar 'Torta de Flor Roxa'. On that occasion, plants were in the flowering stage. Epidemic was rapid and within 80 days most susceptible plants were affected by the disease. Evaluation of resistant and susceptible plants in parental, $\mathrm{F}_{1}, \mathrm{~F}_{2}$ and backcross generations started at 60 days and was weekly repeated until the end of the life cycle of plants which occurred at around 110 days after planting. The line L-802 and cultivars No. 40 and 'Snap' were uniformly susceptible. For the resistant parental population MK-10, there was no visible sign of fungi on leaves and stems, and that was the criterion to classify resistant plants in segregant generations. $F_{1}$ generation from the resistant $\mathrm{x}$ susceptible cross was uniformly susceptible, indicating that the resistance is recessive to susceptibility (Table 1). $\mathrm{F}_{2}$ generations from crosses of MK-10 with L-802 or No. 40 segregated as 3 susceptible : 1 resistant plants. Backcrosses of $F_{1}$ with L-802 or 'Snap' were uniformly susceptible; however, backcross with MK-10, the resistant source, segregated as 1 susceptible : 1 resistant plants. Joint analyses of all generations indicated a monogenic recessive control of resistance to powdery mildew over susceptibility in the cultivar MK-10.

$\mathrm{F}_{3}$ progenies from the crosses L-802 x MK-10 and No. $40 \mathrm{x}$ MK-10 (Table 2), obtained from $\mathrm{F}_{2}$ plants resistant to powdery mildew, were uniformly resistant to the disease, which is consistent with the hypothesis of recessive homozygosis for resistant $F_{2}$ plants and also discards the possibility of escapes in that generation. The breeding line L-802 and the cultivar No. 40 used as controls were uniformly susceptible while MK-10 was resistant to the disease. Of $14 \mathrm{~F} 3$ progenies originated from susceptible $\mathrm{F}_{2}$ plants in both crosses, four were uniformly susceptible and ten segregated as 3 resistant : 1 susceptible plant, which matches with the expected $2 / 3$ of segregant progenies originated from heterozygous $F_{2}$ plants to $1 / 3$ from homozygous ones $\left(\mathrm{X}_{0.05}^{2}=0.15 \mathrm{n} . \mathrm{s}\right)$.

Those results confirm that resistance to powdery mildew in MK-10 is due to a pair of recessive alleles.

Histological analysis. One of the parameters used to study development stages of $E$. pisi correlated to pea plant resistance is the percentage of conidium germination (4). In our study this characteristic 
Table 1. Segregation data for different populations subjected to powdery mildew infection.

\begin{tabular}{|c|c|c|c|c|}
\hline \multicolumn{5}{|c|}{ Observed Segregation } \\
\hline Population & Resistant & Susceptible & Ratio & $X^{2} P=0.05$ \\
\hline MK-10 & 15 & 0 & - & - \\
\hline L-802 & 0 & 23 & - & - \\
\hline No. 40 & 0 & 25 & - & - \\
\hline 'Snap' & 0 & 15 & - & - \\
\hline $\mathrm{F}_{1}(\mathrm{~L}-802 \times \mathrm{MK}-10)$ & 0 & 18 & - & - \\
\hline $\mathrm{F}_{2}(\mathrm{~L}-802 \times \mathrm{MK}-10)$ & 33 & 77 & $3: 1$ & 1.46 \\
\hline $\mathrm{F}_{2}(\mathrm{No} 40 \mathrm{xMK}-10)$ & 29 & 97 & $3: 1$ & 0.25 \\
\hline $\mathrm{BC}\left(\mathrm{F}_{1} \times \mathrm{MK}-10\right)$ & 14 & 12 & $1: 1$ & 0.01 \\
\hline $\mathrm{BC}\left(\mathrm{F}_{1} \times \mathrm{L}-802\right)$ & 0 & 17 & $0: 1$ & - \\
\hline
\end{tabular}

R: number of resistant plants $\mathrm{S}$ : number of susceptible plants

Table 2. Segregation data for $\mathrm{F}$ progenies from resistant and susceptible $\mathrm{F}$ plants subjected to powdery mildew.

\begin{tabular}{lccccc}
\hline & \multicolumn{3}{c}{ F $_{2}$ Plants } & & F $_{3}$ Progenies \\
\cline { 2 - 5 } CROSS & Number & Reaction & R & St \\
\hline L-802 x MK-10 & 02 & R & 02 & - \\
No.40 x MK-10 & 06 & S & - & 04 \\
& 08 & R & 08 & - \\
\hline
\end{tabular}

$\mathrm{R}=$ resistant $\quad \mathrm{Sg}=$ segregant $\quad \mathrm{St}=$ susceptible

Table 3. Development stages of E. pisi in resistant and susceptible pea plants for different populations.

\begin{tabular}{|c|c|c|c|c|}
\hline Population & $\begin{array}{c}\text { Reaction to } \\
\text { powdery mildew }\end{array}$ & $\begin{array}{l}\text { Germinated conidia } \\
\text { with appresorium \% }\end{array}$ & $\begin{array}{c}\text { Colonization } \\
(\%)\end{array}$ & $\begin{array}{c}\text { Number of haustoria } \\
\text { per colony }\end{array}$ \\
\hline MK-10* & $\mathrm{R}$ & $90.2 \mathrm{a}$ & $1.6 \mathrm{a}$ & $0.4 \mathrm{a}$ \\
\hline L-802 & $\mathrm{S}$ & $85.0 \mathrm{a}$ & $30.1 \mathrm{~b}$ & $1.2 \mathrm{abc}$ \\
\hline$(\mathrm{L}-802 \times \mathrm{Mk}-10) \mathrm{F}_{2}$ & $\mathrm{R}$ & $93.0 \mathrm{a}$ & $1.8 \mathrm{a}$ & $0.6 \mathrm{ab}$ \\
\hline No. 40 & $\mathrm{~S}$ & $\mathrm{a} 82.2 \mathrm{a}$ & $69.3 \mathrm{c}$ & $2.0 \mathrm{bcd}$ \\
\hline$(\mathrm{No} .40 \times \mathrm{MK}-10) \mathrm{F}_{2}$ & $\mathrm{R}$ & $93.3 \mathrm{a}$ & $1.7 \mathrm{a}$ & $0.4 \mathrm{a}$ \\
\hline$\left(\right.$ No.40xMK-10)F $\mathrm{F}_{2}$ & $\mathrm{S}$ & $94.8 \mathrm{a}$ & $88.2 \mathrm{c}$ & $2.2 \mathrm{bcd}$ \\
\hline 'Torta de Flor Roxa' & $\mathrm{S}$ & $77.0 \mathrm{a}$ & $70.2 \mathrm{c}$ & $2.8 \mathrm{~d}$ \\
\hline $\mathrm{CV}(\%)$ & - & 14.6 & 8.2 & 37.5 \\
\hline
\end{tabular}

* Moderate powdery mildew resistance

Means followed by the same letter within each column do not differ significantly (Tukey's test) at 5\% probability

$\mathrm{R}=$ Resistant; $\mathrm{S}=$ Susceptible 
was evaluated but data is not shown. Inoculation was natural and the spores present on leaf surfaces could include old, non-viable ones, which would influence the recorded germination data. The percentage of conidia with appresorium formation, however, does not depend on the spore age since it was determined for germinated conidia. There was no difference among parentals or between resistant and susceptible plants and segregant generations for this characteristic (Table 3). The same results were obtained by Poulter et al. (11), who compared wild pea introductions, and by Fondevilla et al. (4), who studied susceptible and resistant cultivars with the two reported recessive genes $\left(e r_{l} e r_{2}\right)$ providing resistance to the pathogen. This fact is in agreement with the results of Niks and Rubrales (10), who considered that conidium germination is not a factor involved in resistance against Erysiphe species.

As regards the percentage of colonization and the number of haustoria per colony, the resistant parent MK-10 differed from the susceptible ones No.40, 'Snap', and from controls 'Torta de Flor Roxa'. Resistant plants from segregant $\mathrm{F}_{2}$ populations behaved similarly to the resistant parents for this characteristic. The highest values for both characteristics were found for susceptible lines and segregants.

Intermediate values were obtained for parental L-802 which presented $30.1 \%$ colonization and 1.2 haustoria per colony, suggesting that it is moderately resistant to powdery mildew. This line was obtained at the School of Agronomical Sciences, UNESP, Botucatu Campus, by crossing the pea cultivar 'Triofin', considered resistant to E. pisi in Brazil (8), with the susceptible cultivar 'Torta de Flor Roxa', and selecting under natural epidemic conditions.

Since resistance of 'Triofin' is polygenically inherited and variable under high inoculum pressure, its expression is inferior when compared to that of MK-10.

High appresorium production and low colonization percentage suggest that resistance of progenies and MK-10 is due to a defense mechanism established before penetration. Although the technique employed in this study does not allow the identification of such a mechanism, the latter can be postulated to be due to lignifications and papilla formation on the cell walls. A high lignification rate has been the first line of defense of wheat against powdery mildew (Blumeria graminis) (1), and papilla formation is responsible for resistance against powdery mildew (Sphareotheca pannosa) in the rose species Rosa wichurainae and $R$. laevigata (3).

Hypersensitivity reaction expressed by localized cell death was recorded in resistant plants and in the cultivar MK-10 when the lignification-papilla barrier was overcome. This may explain the low number of haustoria found in those populations. High percentage of colonization (92.5\%) was found by Fondevilla et al. (4) in association with the presence of the gene $e r_{2}$ and with the susceptible lines of pea; however, all resistant lines homozygous to $e r_{l}$ had high appresorium formation but an average of $0.48 \%$ established colonies and a low number of haustoria per colony. Our findings show that MK-10 and resistant segregant plants from its crosses behaved similarly and suggest that the gene $e r_{l}$ is present in that population.

The cultivar MK-10, a closed pedigree line, released by a seed company proved to be a valuable source of resistance for utilization in pea breeding programs in Brazil as an alternative to 'Triofin' with quantitative resistance inheritance.

\section{ACKNOWLEGMENT}

The authors wish to thank Conselho Nacional de Desenvolvimento Científico e Tecnológico (CNPq) for the fellowship awarded to the first author.

\section{REFERENCES}

1. Bhuiyan N.H.; Selvaraj, G.; Wei, Y., and King, G. Role of lignification in plant defense. Plant Signaling \& Behavior 4 Austin, v.4, p.158-159, 2009.

2. Carver, T.L.W.; Roberts, P.C., Thomas, B.J.; Lyngkjaer, M.F. Inhibition of Blumeria graminis germination and germling development within colonies of oat mildew. Physiological and molecular Plant Pathology, v.58, p.209-228, 2001.

3. Dewitte, A.; Leus, L.; Van Huylenbroeck, J.; Van Bockstaele, E.; Mofte, M. Resistance reactions in rose leaves against powdery mildew (Podophaera pannosa). Acta Horticulturae, Leuven, v.751, p.183-188, 2007.

4. Fondevilla, S.; Carver, T.L.W.; Moreno, M.T.; Rubiales, D. Macroscopic and histological characterization of genes erl and $e r 2$ for powdery mildew resistance in pea. European Journal of Plant Pathology, Dodrecht, v.115, p. 309-321, 2006.

5. Giordano, L.B.; Reifschneider, F.J.B. Resistência ao oídio (causado por Erysiphe pisi D.C.) em ervilha (Pisum sativum L. cv. Triofin). Horticultura Brasileira, Brasília, v. 2, p. 35 $37,1984$.

6. Giordano, L.D.B; Reifschneider, J.B.; Nascimento, W.M. Ervilha: cultivares para produção de grãos secos. 1988. Disponível em: <http://www.cnph.embrapa.br/paginas/produtos/cultivares/ervilha_graos_secos.htm>. Acesso em: 04 abr. 2010.

7. Giordano, L.D.B.; Nascimento, W.M.; Santos, J.R.M. dos. Ervilha: Cultivares para produção de grãos verdes. 1996. Disponível em: <:http://www.cnph.embrapa.br/paginas/produtos/cultivares/ervilha_graos_verdes.htm>. Acesso em: 04 abr. 2010.

8. Heringa, R.J.; Vannorel, A.; Tazelaar, M.F. Resistance to powdery mildew in pea. Euphytica, Dordrecht, v.18, p. 163 169,1969

9. Stangarlin, J.R.; Franzener, G.; Pascholati, S.F. Doenças da ervilha. In: Kimati, H.; Amorim, L.; Rezende, J.A.M.; Bergamin Filho, A.; Camargo, L.E.A. (Eds.). Manual de fitopatologia. São Paulo: Agronômica Ceres, 2005. p. 311-317.

10. Niks, R.E.; Rubiales, D. Potentially durable resistance mechanisms in plants to specialised fungal pathogens. Euphytica, Dordrecht, v. 124, p. 201-216, 2002.

11. Poulter, R.; Harvey, L.; Burritt, D.J. Qualitative resistance to powdery mildew in hybrid sweet peas. Euphytica, Dordrecht, v. 133, p. 349-358, 2003.

12. Tiwari, K.R.; Panner, G.A.; Warkentin, T.D. Inheritance of powdery mildew resistance in pea. Canadian Journal of Plant Science, Otawa v. 77, p. 307-310, 1997.

13. Stadink, J.; Rivera, A.M.C. Oídios. Jaguaríuna: EMBRAPA Meio Ambiente, 2001. 484p.

14. Strickberger, M.W. Genetics. New York: The Macmillan, 1976. 570 p. 